\title{
Comparison between perfusion and balloon techniques for performing anorectal manometry in children with intestinal constipation ${ }^{1}$
}

\section{Comparação das técnicas de balão e de perfusão para a realização de manometria anorretal em crianças portadoras de constipação intestinal}

\author{
Geraldo Magela Nogueira Marques ${ }^{I}$, José Luiz Martins"I, Vânia Dolores Rodrigues Perdigão Nobre ${ }^{\text {III }}$ \\ ${ }^{\text {I }}$ Master, UNIFESP, Felow PhD degree, Sao Paulo University (USP), Brazil. \\ II PhD, Associate Professor, Division of Pediatric Surgery, Department of Surgery, UNIFESP, Sao Paulo, Brazil. \\ III Master, UNIFESP, Sao Paulo, Brazil.
}

\begin{abstract}
Introduction: Two anorectal manometry techniques have commonly been utilized: the perfusion technique and the balloon technique. Purpose: To compare both techniques in children with intestinal constipation who had not undergone surgical treatment for its correction. Methods: Thirty-nine children aged between four and fourteen years underwent anorectal manometry using both techniques at random. Resting pressure, pressure response to voluntary contraction, coughing and perianal stimulation, maximum pressure on the anal canal pressure curve, and presence of rectosphincteric reflex were registered and submitted to statistics. Vectorgraphy of the sphincter muscle complex was obtained by perfusion technique. Results: The statistical comparison between the techniques revealed statistically significant differences in resting pressure $(\mathrm{p}=0.041)$, pressure response to voluntary contraction $(\mathrm{p}=0.026)$ and maximum pressure within the pressure curve $(\mathrm{p}=0.010)$. The rectosphincteric reflex was demonstrated in 21 patients by both techniques. Conclusions: The perfusion technique presented greater sensitivity in the following parameters: resting pressure, pressure response to voluntary contraction and maximum pressure within the pressure curve. The methods studied are equivalent regarding the measurement of pressure responses to coughing and perianal stimulation and the investigation of rectosphincteric reflex.
\end{abstract}

Key words: Child. Manometry. Constipation. Hirschsprung Disease.

\section{RESUMO}

Introdução: A manometria anorretal tem sido aceita como uma técnica objetiva de estudar a função do complexo muscular esfincteriano. Duas técnicas para o mesmo exame têm sido utilizadas: por perfusão e por balão. Objetivo: Comparar as técnicas entre as crianças portadoras de constipação intestinal que não foram submetidas a tratamento cirúrgico como forma de tratamento. Métodos: Trinta e nove crianças com idades entre quarto e quatorze anos foram submetidas à Manometria anorretal utilizando-se ambas as técnicas de forma randomizada. Analizou-se a pressão de repouso, a pressão de contração voluntária, a pressão de contração reflexa, a pressão máxima de contração, o reflexo reto-esfincteriano. Além desses parâmetros, o vetorgrama do canal anal foi estudado pela técnica de perfusão. A análise estatística foi feita por meio de Wilcoxon signed rank test. Resultados: A comparação estatística entre as técnicas revelou diferenças significantemente estatísticas nos parâmetros: pressão de repouso $(\mathrm{p}=0.041)$, Pressão de contração voluntária $(\mathrm{p}=0.026)$ e pressão máxima de contração $(\mathrm{p}=0.010)$. Não houve diferença estatisticamente significante nos parâmetros: pressão de contração reflexa por tosse $(\mathrm{p}=0.141)$ ou por estimulação perianal ( $\mathrm{p}=0.117)$. O reflexo reto-esfincteriano foi demonstrado em 21 pacientes em ambas as técnicas. Conclusões: A técnica de perfusão tem maior sensibilidade para os seguintes parâmetros: pressão de repouso, pressão de contração voluntária e pressão máxima de contração. As técnicas se equivalem no que diz respeito à pressão de contração reflexa e reflexo reto-esfincteriano.

Descritores: Criança. Manometria. Constipação intestinal. Doença de Hirschsprung.

${ }^{1}$ Research performed at Division of Pediatric Surgery, Department of Surgery, Federal University of São Paulo (UNIFESP), Brazil.

\section{Introduction}

Physiological evaluations of the anorectal region have been performed since 1878 by Gowers ${ }^{1}$, when the rectosphincteric reflex or rectoanal inhibitory reflex was first described. This reflex has been studied in patients with neurological alterations ${ }^{2}$ and anesthetized patients $^{3}$. Four decades ago, anorectal manometry started to be utilized in the evaluation of evacuation disturbances, with the use of simplified techniques ${ }^{4,5}$. 
Several techniques have been proposed when performing this examination: perfusion, balloons and transducing probes ${ }^{6-13}$.

From 1995 on, at the Anorectal Manometry Laboratory of the Pediatric Coloproctology Unit of the Division of Pediatric Surgery (UNIFESP), we have been using the balloon technique on computerized electromanometry, with the installation of a specific software.

In February 2001, we also began manometric studies using the 4-channel perfusion technique, with the possibility of obtaining a three-dimensional schematization of the sphincter apparatus, i.e. vectorgraphy.

The purpose of this study is to evaluate the anorectal manometry performed with a 4-channel continuous perfusion in comparison to manometry performed with balloons, in children with intestinal constipation.

\section{Methods}

The study was approved by the Research Ethics Committee of Universidade Federal de São Paulo - Escola Paulista de Medicina, São Paulo, SP, Brazil. A written consent was obtained from the children's parents. The study was conducted in children with chronic constipation sent to the Pediatric Surgery Discipline, Pediatric Coloproctology Unit.
Inclusion criteria: children aged 4-14 years, with symptoms of chronic constipation such as stool frequency of less then three times per week, painful passage or stool retention with and without soiling for at least six months.

Exclusion criteria: children submitted to any surgical procedure that intended to correct or ameliorate the constipation symptoms, debilitating diseases, neurological abnormalities and mental deficiency.

Selected children were submitted to anamnesis, physical examinations, barium enema and then to computerized anorectal manometry utilizing two techniques: continuous perfusion and balloon, randomly.

Manometries were performed without sedation. All the children received phosphate enema, $10 \mathrm{~mL} / \mathrm{kg}$ (maximum $120 \mathrm{~mL}$ ), about 12 hours before admission. When the fecal retention was important, the children received phosphate enema for 3 to 5 days before being submitted to computerized anorectal manometry. The choice of technique to be used first was randomly established before children were admitted to the anorectal manometry laboratory. In the computerized anorectal manometry using the perfusion technique (Figure 1), a flexible catheter of 4 millimeters ( $\mathrm{mm}$ ) in diameter was used, with 4 radially-distributed orifices and a lumen to inflate a latex balloon at its tip, with a maximum capacity of 200 milliliters $(\mathrm{mL})$.

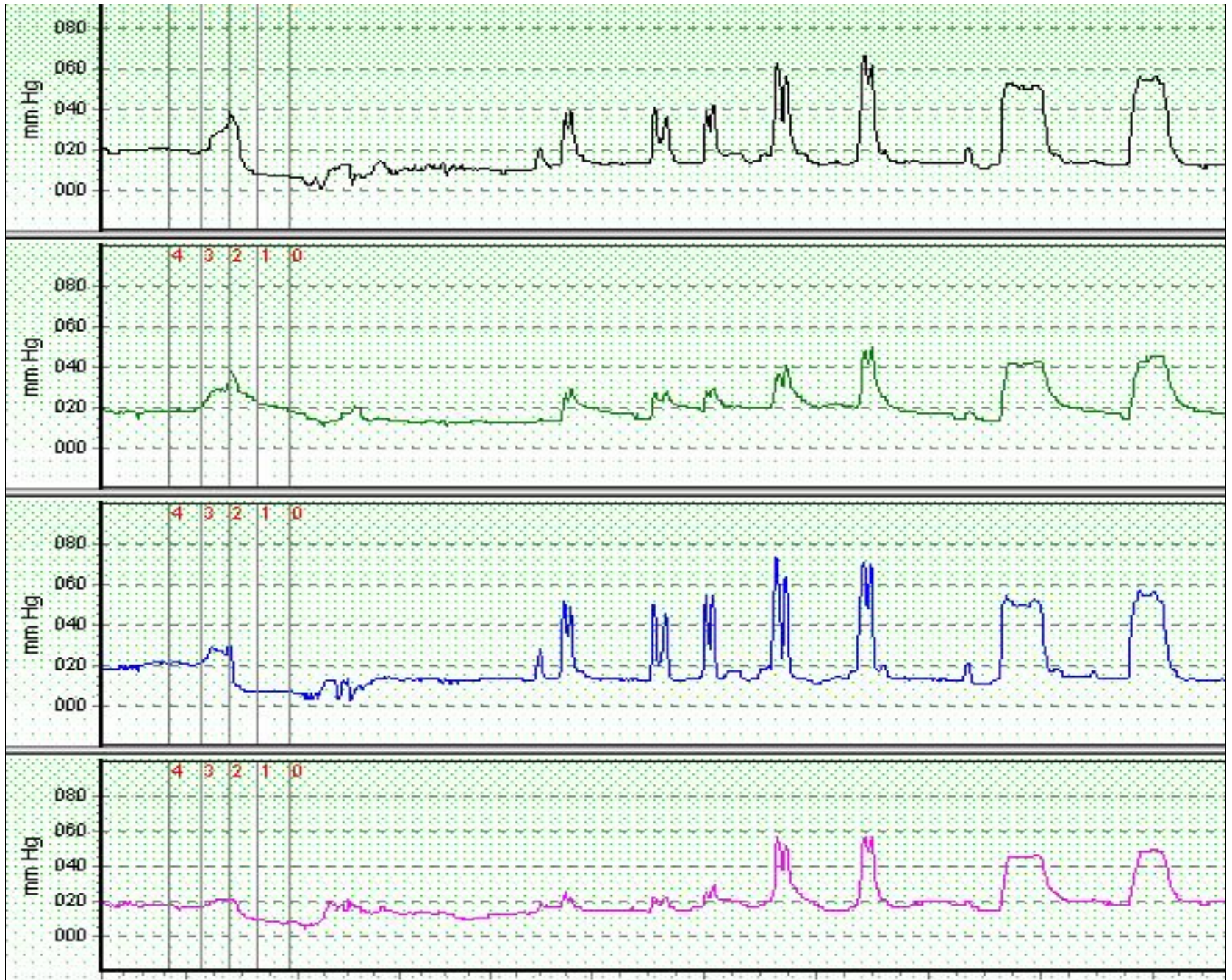

FIGURE 1 - Computarized anorectal manometry using the perfusion technique 
The distance between the perfusion orifices and the balloon was two $\mathrm{cm}$.

This catheter was connected to a 4-channel infusion pump with a pneumatic $\mathrm{CO}_{2}$ system that maintained the infusion pressure at one atmosphere (atm), with a continuous flow of 0.56 milliliters/ minute $(\mathrm{mL} / \mathrm{min})$ of distilled water. The pressure data obtained were amplified and the results were recorded and analyzed using the Proctomaster ${ }^{\circledR}$-Dynamed software. In the computerized anorectal manometry using the balloon technique (Figure 2), a flexible catheter of $5 \mathrm{~mm}$ in diameter was utilized, with a $5 \mathrm{~mL}$ balloon, calibrated at 100 millimeters of mercury $(\mathrm{mmHg})$, and with a lumen at its tip for inflating a latex balloon with a maximum capacity of $200 \mathrm{~mL}$.

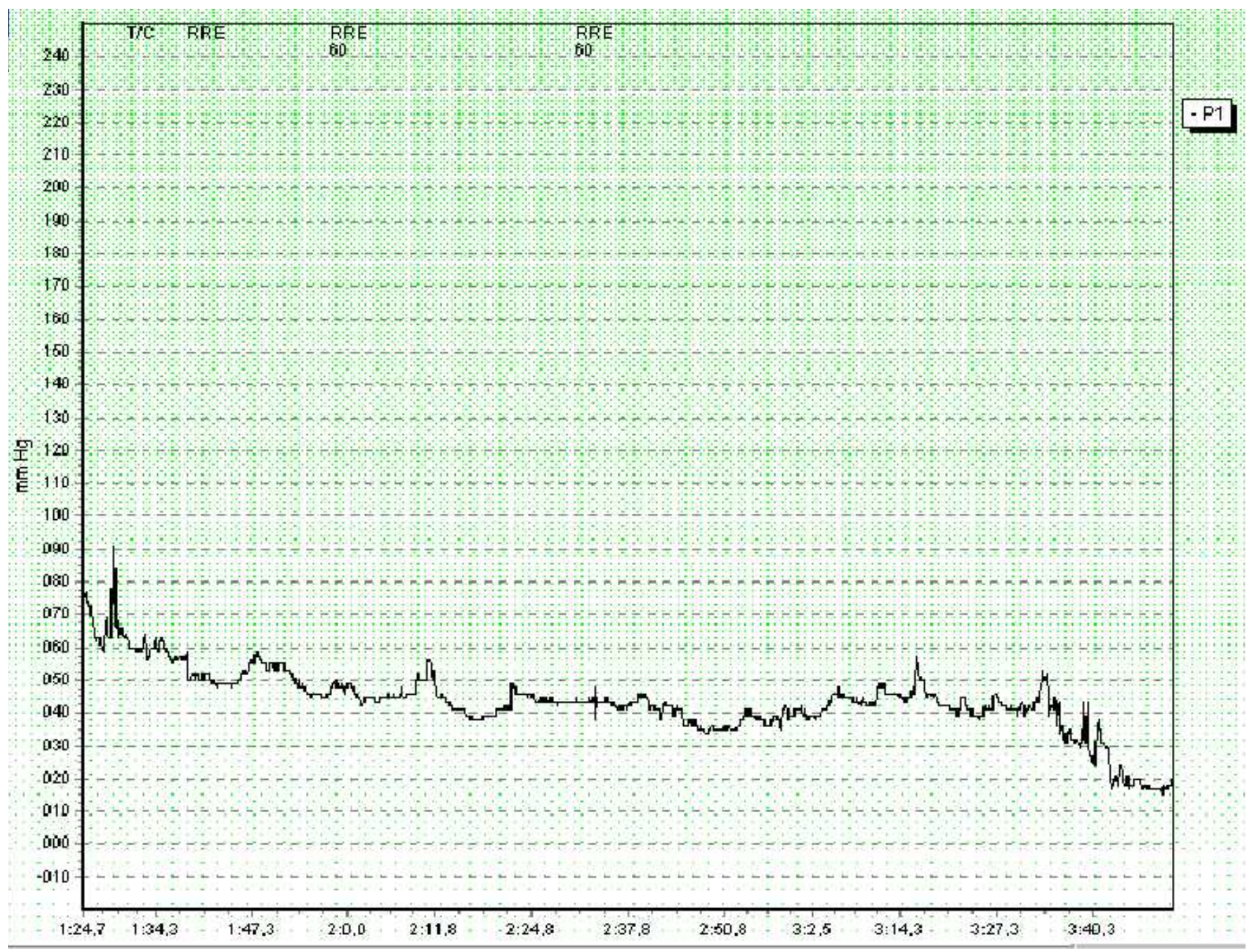

FIGURE 2 - Computarized anorectal manometry using the baloon technique

The distance between the balloons was two $\mathrm{cm}$. The data from the pressure transducer was amplified and the results obtained were recorded using the Proctomaster ${ }^{\circledR}$-Dynamed software. The patient was placed in right lateral decubitus, with the left knee bent and the right knee extended. The catheter was lubricated with a water-based substance and calibrated at zero (no load). It was then introduced into the anal canal up to the mark of five $\mathrm{cm}$ from the anal verge. The graphics displayed on the computer screen registered the movement of the catheter in such a way as to determine the extent of the anal canal, the zone of greatest pressure of the sphincter apparatus and its location in relation to the anal verge. Once the zone of greatest pressure had been identified, the catheter was reintroduced in such a way as to be placed within this zone of greatest pressure to record it.

Manometric parameters studied: 1) resting pressure (RP); 2) pressure response to coughing $(\mathbf{C R}) ; 3)$ pressure response to voluntary contractions (VC); 4) maximum pressure obtained within the pressure curve (MP); 5) pressure response during perianal stimulation (PA); 6) rectosphincteric reflex (RER). For the anorectal manometry technique using a perfusion catheter, three-dimensional schematizations were also obtained from the graphs related to the simple pressure curves (Vectorgraphy) (Figure 3). 


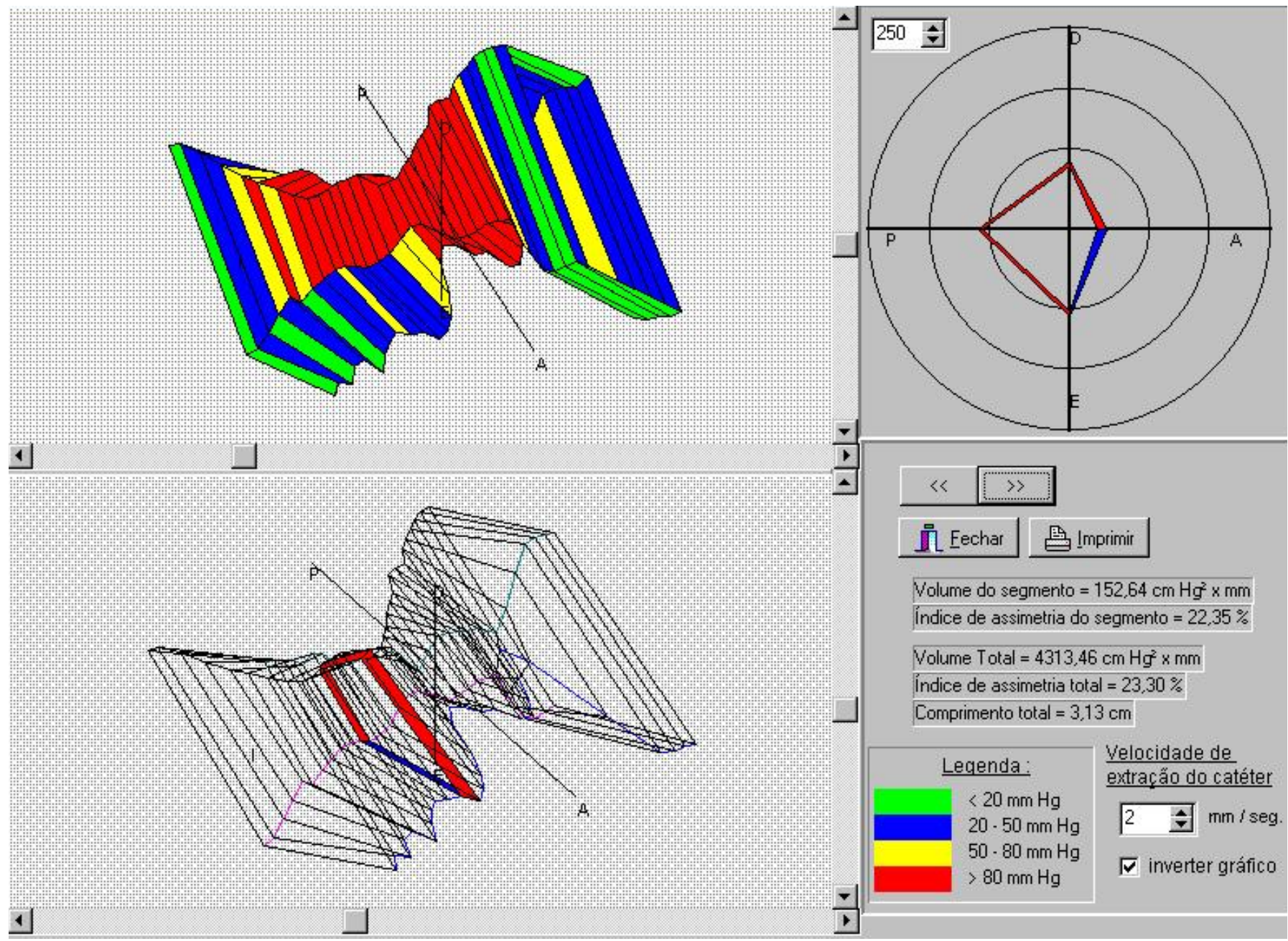

FIGURE 3 - Vectorgraphy (Profilometry)

For resting pressure (RP), after the introduction of the catheter, we waited until there was pressure stabilization in patient's anorectal sphincter. For pressure response to voluntary contraction (VC), the patients were asked to contract the sphincter apparatus three times at intervals of 30 seconds, in order to record the voluntary contraction pressure. We took as a parameter for the study, the most vigorous contraction which caused the highest elevation on pressure recording. Maximum pressure (MP) of the sphincter apparatus was obtained from the maximum pressure recorded within the pressure curve for the balloon technique and from the average of this same measurement for the four perfusion channels. For pressure response to perianal stimulus (PA), we stimulated the perianal region at $0.5 \mathrm{~cm}$ from the anal verge twice at intervals of 15 seconds, using a metallic object with a blunt point, in such a way as to obtain a reflex response with a variation in sphincter pressure. Investigation of rectosphincteric reflex (RER) was done by the insufflations of air into the rectal balloon using a syringe, at volumes of 20,40 and $60 \mathrm{ml}$. We kept the balloon inflated for 10 seconds or until sphincter pressure was normalized. After emptying the rectal balloon, we waited for the reestablishment of resting pressure before performing a second investigation of the rectosphincteric reflex. The three-dimensional schematization (vectorgraphy) of the sphincter apparatus could only be obtained by perfusion technique.

Wilcoxon signed rank test method was used to compare the means of each group of measurements made, since their distribution was not normal. Results were considered statistically significant when $p \leq 0.05$.

\section{Results}

When mean values and standard deviations of the pressures obtained were compared, we observed the results shown in Table 1. 
TABLE 1 - Statistical comparison of the means of pressures obtained

Resting pressure

Perfusion

Balloon

Pressure response to coughing

Perfusion

Balloon

Pressure response to voluntary contraction
$53.00 \pm 24.48 \mathrm{mmHg}$

$46.20 \pm 32.20 \mathrm{mmHg}$ $p=0.141$

$108.60 \pm 46.26 \mathrm{mmHg}$

$99.10 \pm 40.43 \mathrm{mmHg}$

Perfusion

Balloon
$111.80 \pm 43.73 \mathrm{mmHg}$

$97.4 \pm 38.40 \mathrm{mmHg}$
Maximum pressure within pressure curve

Perfusion

Balloon $p=0.010$

$133.50 \pm 50.04 \mathrm{mmHg}$

$117.00 \pm 49.32 \mathrm{mmHg}$

Pressure response to perianal stimulation

\section{$97.10 \pm 39.74 \mathrm{mmHg}$}

$p=0.117$
Balloon

Perfusion
$87.90 \pm 42.31 \mathrm{mmHg}$
The difference found between mean resting pressure for the balloon technique $(46.20 \pm 32.20 \mathrm{mmHg})$ and mean resting pressure for the perfusion technique $(53.00 \pm 24.48 \mathrm{mmHg})$ was statistically significant $(p=0.041)$.

The difference found between mean pressure response to coughing for the balloon technique $(99.10 \pm 40.43 \mathrm{mmHg})$ and mean pressure response to coughing for the perfusion technique $(108.60 \pm 46.26 \mathrm{mmHg})$ was not statistically significant $(p=0.141)$.

The difference found between mean pressure response to voluntary contraction for the balloon technique $(97.40 \pm 38.40 \mathrm{mmHg})$ and mean pressure response to voluntary contraction for the perfusion technique $(111.80 \pm 43.73 \mathrm{mmHg})$ was statistically significant $(p=0.026)$.

The difference found between mean maximum pressure within the pressure curve for the balloon technique $(117.00 \pm 49.32 \mathrm{mmHg})$ and mean maximum pressure within the pressure curve for the perfusion technique $(133.50 \pm 50.04 \mathrm{mmHg})$ was statistically significant $(p=0.010)$.
The difference found between mean pressure response to perianal stimulation for the balloon technique $(87.90 \pm 42.31$ $\mathrm{mmHg}$ ) and mean pressure response to perianal stimulation for the perfusion technique $(97.10 \pm 39.74 \mathrm{mmHg})$ was not statistically significant $(p=0.117)$.

Twenty-one patients had a positive response in the investigation of the rectosphincteric reflex, both via perfusion technique and balloon techniques.

\section{Discussion}

Pressure response is the predominant factor in maintaining fecal continence ${ }^{11,12}$. The muscle tonus of internal and external sphincters contribute towards resting pressure, with the internal sphincter responsible for $85 \%$ of this pressure and the external sphincter for only $15 \% \%^{1,8,12}$. Highest values were encountered when perfusion catheters were utilized.

A sudden rise in intra-abdominal pressure provokes a 
reflex contraction of the external sphincter, as happens during coughing or crying. This sudden contraction increases sphincter pressure values so that they are higher than rectal pressure, thereby contributing towards fecal continence. This response is considered to be a reflex from pelvic receptors and acts on external sphincter and puborectal bundle $\mathrm{e}^{10-15}$

Contraction of the external sphincter may be voluntarily controlled and is associated with the contraction of the puborectal bundle. Voluntary contraction raises pressure throughout the anal canal, but the pressure is greatest in the most distal region, where external sphincter fibers are located. The loss of capacity to perform voluntary contractions or voluntary contractions that only provokes small pressure rises as seen in anorectal manometry is the most important factor in persistence of fecal incontinence ${ }^{1,11,12,14}$.

Among patients studied, higher pressure response values for voluntary contraction were observed when they underwent perfusion catheter examination.

Maximum sphincter pressure, obtained from the pressure curve, is the result of interaction between internal and external sphincter functions. It must be taken into account that the movement of the catheter to obtain the pressure curve stimulates the anal canal and that such stimulation determines higher pressure values than when the catheter is stationary ${ }^{12,13,15}$.

Upon stimulating the skin in perianal region, a reflex contraction of the rectosphincteric complex is obtained, which comes mainly from the contraction of external sphincter. It depends on the sensitivity of the skin in that region and reflex transmission of the stimuli to the nerve centers and their motor response. When balloon and perfusion techniques were compared, the results were similar.

The rectosphincteric reflex in response to rectal distention is associated with suppression of pressure oscillations by contractile waves and relaxation of internal sphincter. Absolute or relative amplitude of the relaxation of internal sphincter depends on its preexisting muscle tone and the magnitude of its collaboration in maintaining pressure response ${ }^{4}$.

Among chronically constipated children there may be greater rectal accommodation and an increase in the threshold of rectal sensitivity because of the greater-than-normal elasticity of the rectal wall ${ }^{4,11}$.

We obtained the recording of the rectosphincteric reflex via air insufflation into a balloon positioned in the rectum, using progressive volumes of 20,40 and $60 \mathrm{~cm}^{3}$ of air. Rectosphincteric reflex can also be obtained by injection of water or free air into the rectum. We chose to use balloons, since the injection of water may cause contraction of the external sphincter because of the sensitivity of the anal canal, thereby falsifying the result. Air drainage after obtaining the reflex is difficult, it may be impossible to repeat the process $^{13}$.

Anorectal manometry for diagnosis or exclusion of Hirschsprung's disease has almost universal acceptance. In Hirschsprung's disease, this reflex is not obtained from any length of rectal segment $t^{3,5,10,11,13}$. In practical terms, if the rectosphincteric reflex can be demonstrated, the hypothesis of Hirschsprung's disease can be excluded. On the other hand, the absence of the rectosphincteric reflex may be indicative of Hirschsprung's disease or it may be due to technical problems of execution or recording the reflex, or because of the immaturity of its development ${ }^{10,13,16,17}$.
Once a positive result from the investigation of the rectosphincteric reflex is obtained, the technique or the type of device used does not matter ${ }^{16}$. Results coincided when both techniques were used in the investigation of the rectosphincteric reflex in the studied patients.

The utilization of a catheter with four radial perfusion channels permits simultaneous recording of $90^{\circ}$ segments of the muscle complex, which after digitizing and analyzing furnish the average of these measurement points and, in association with the technique of withdrawing the catheter, three-dimensional schematizations of the anal canal and the sphincter muscle complex may be obtained.

Such three-dimensional schematization, known as profilometry or vectorgraphy, permits the identification of the anal canal positioning anomalies in relation to the sphincter apparatus, which can direct the treatment of such patients. In addition, vectorgraphy is considered the best sphincter evaluation parameter, since it combines pressure and extension measurements of the sphincter complex, thus permitting the evaluation of lesions or weaknesses located in the sphincter muscle complex ${ }^{6,7}$.

Vectorgraphy has the main purpose of studying radial symmetry of the sphincter complex. Radial or localized asymmetry of the sphincter apparatus may denote a lesion of the muscle complex or a positional anomaly of the anus in relation to $i t^{6,7,12}$.

Stepped manual withdrawal of the catheter for recording pressure in different segments of the sphincter apparatus is more efficacious than continuous pulling using extraction devices, since it permits stationary periods for sphincter stabilization during the intervals of the withdrawal. Technical artifact of stimulation caused by the withdrawal may be minimized by adequate lubrication of the catheter ${ }^{11}$.

Comparison of the two measurement techniques for the same parameter may be a statistical and clinical challenge when the methods studied are not "gold standard". The method most commonly encountered in the literature for this type of comparison is the application of the measurement techniques to the same group of patients and comparison of the non-parametric results with non-normal distribution ${ }^{7,18}$, as it was done here.

Perfusion technique is considered to be the most physiological manner of obtaining measurements of resting pressure of the anal canal. It may cause discomfort to patients because of the escape of liquids ${ }^{12}$, although we did not notice any alteration in our patients that might have denoted such discomfort.

A relatively high correlation between the measurement results from the two techniques was observed. The demonstration of this correlation becomes important when dealing with the introduction of a new technique substituted by another, or when affirming that one technique has more advantage than the other ${ }^{18,19}$.

Despite the correlation between techniques, pressure differences recorded ensure that these techniques will not be utilized in alternation with the periodic evaluations of such patients.

Moreover, the perfusion technique permits profilometry to be performed, producing a spatial image of the sphincter region that is not feasible with the balloon technique due to its methodological characteristics.

Based on these data, perfusion technique and computerized anorectal manometry is now the procedure of choice at the Pediatric Surgery Division, Department of Surgery of UNIFESP. 


\section{Conclusions}

The perfusion technique has greater sensitivity to the following parameters: resting pressure, pressure response to voluntary contraction and maximum pressure within the pressure curve. The methods studied are equivalent to the measurement of pressure responses to coughing and perianal stimulation and the investigation of rectosphincteric reflex.

\section{References}

1. Gowers WR. The automatic action of the sphincter ani. Proc R Soc Med. 1878;26:77-84.

2. Dennys-Brown D, Robertson EG. An investigation of the nervous control of defecation. Brain. 1935;58:256-310.

3. Duthie HL, Watts AM. Contribution of the external sphincter to the pressure zone in the anal canal. Gut. 1965;6:64-8.

4. Bigelli RHM, Fernandes MIM, Vicente YAMV, Dantas RO, Galvão LC, Campos AD. Anorectal manometry in children with chronic functional constipation. Arch Gastroenterol. 2005;42:178-81.

5 . Bowes KL, Kling S. Anorectal manometry in premature infants. J Pediatr Surg. 1979;14:533-5.

6. Jorge JNM, Wexner SD. Anorectal manometry: techniques and clinical applications. Southern Med J. 1993;86:924-31.

7. Martins JL, Pinus J. Anorectal manometry in the child assessment of 1153 examinations performed from 1987 to 1995. Rev Hosp Sao Paulo. $1995 ; 6: 80-2$

8. Martins JL, Esteves E. Computerized anorectal manometry in pediatric patients: initial experience. Rev Hosp São Paulo Esc Paul Med. 1995;6:83-6 .
9. Martins JL, Esteves E. Evaluación de la motilidad anorrectal por manometria computadorizada en la infancia. Rev Cir Infantil. 1996;6:177-80. 10. Sutphen J, Borowitz S, Ling W, et al. Anorectal manometric examination in encopretic-constipated children. Dis Colon Rectum. 1997;40: 1051-5. 11. Schuster T, Lagler F, Pfluger T, Dietz HG, Joppich I. A computerized vector manometry and MRI study in children following posterior sagittal anorectoplasty. Pediatr Surg Int. 2001;17: 48-53.

12. Sun WM, Rao SS. Manometric assessment of anorectal function. Gastroenterol Clin North Am. 2001;30:15-32.

13. Andromanakos N, Skandalakis P, Troupis T, Fillippou D. Constipation of anorectal outlet obstruction: pathophysiology, evaluation and management. J Gastroenterol Hepat. 2006;21:638-46.

14. Martins JL. Manometria anorretal. In: Penna FJ, Wheba J, Fagundes Neto U. Gastroenterologia pediátrica. Rio de Janeiro: Editora MEDSI; 1983. p. 641-50.

15. Martins JL, Pinus J, Pinus Jq. Manometria anorretal. In: Penna FJ, Wheba J, Fagundes Neto U. Gastroenterologia pediátrica. 2ed. Rio de Janeiro: Editora MEDSI; 1991. p. 651-6.

16. Felt-Bersma RJ, Sloots CE, Poen AC, Cuesta MA, Meuwissen SG. Rectal compliance as a routine measurement: extreme volumes have direct clinical impact and normal volumes exclude rectum as a problem. Dis Colon Rectum. 2000;43:1732-8.

17. Glia A, Lindberg G, Nilsson LH, Mihocsa L, Akerlund JE. Clinical value of symptoms assessment in patients with constipation. Dis Colon Rectum. 1999;42:1401-10.

18. Murray GD, Miller R. Statistical comparison of two methods of clinical measurement. Br J Surg. 1990;77:384-7.

19. Mishalany H, Suzuki H, Yokoama J. Report on the First International Symposium of Anorectal Manometry. J Pediatr Surg .1989;24:356-9.

Conflict of interest: none

Financial source: none

\section{Correspondence:}

Geraldo Magela N. Marques

Rua Dona Vitória, 473/13

11440-170 Guarujá - SP Brazil

geraldomnm@gmail.com

Received: March 11, 2008

Review: May 12, 2008

Accepted: June 17, 2008

\section{How to cite this article}

Marques GMN, Martins JL, Nobre VDRP. Comparison of perfusion and balloon techniques for performing anorectal manometry among children with intestinal constipation. Acta Cir Bras. [serial on the Internet] 2008 Sept-Oct;23(5). Available from URL: http://www.scielo.br/acb 